\title{
Seed Storage Indicates the High Stability of Babaçu Oil (Attalea vitrivir Zona)
}

\author{
Higor Fernando Salvador ${ }^{1}$, Sirleane Martins Rocha ${ }^{1}$, Sônia Ribeiro Arrudas ${ }^{1}$, Leonardo Monteiro Ribeiro ${ }^{1}$, \\ Vany Perpetua Ferraz ${ }^{2}$, Henrique Maia Valério ${ }^{1}$, Geraldo Aclécio Melo ${ }^{1}$, Paulo Henrique Fidêncio ${ }^{3}$ \\ \& Marcio Antonio Silva Pimenta ${ }^{1}$ \\ ${ }^{1}$ Center for Biological and Health Sciences, Department of General Biology, State University of Montes Claros, \\ Darcy Ribeiro University Campus, Montes Claros, Minas Gerais, Brazil \\ ${ }^{2}$ Department of Chemistry, Federal University of Minas Gerais, Belo Horizonte, Minas Gerais, Brazil \\ ${ }^{3}$ Department of Chemistry, Federal University of the Jequitinhonha and Mucuri Valleys, Diamantina, Minas \\ Gerais, Brazil \\ Correspondence: Marcio Antonio Silva Pimenta, Center for Biological and Health Sciences, Department of \\ General Biology, State University of Montes Claros, Darcy Ribeiro University Campus, Vila Mauricéia, Zip \\ Code 39401-089, Montes Claros, Minas Gerais, Brazil. E-mail: marcio.pimenta@unimontes.br
}

Received: September 21, 2018

Accepted: November 2, 2018

Online Published: January 15, 2019

doi:10.5539/jas.v11n2p489

URL: https://doi.org/10.5539/jas.v11n2p489

\begin{abstract}
Because the babaçu palm (Attalea vitrivir) has been considered for incorporation into programs of biofuel production, in this work we evaluated the influence of the geographic origins and storage conditions of babaçu palm seeds on the quantity and quality of their extracted oils. Seeds harvested from three different areas were stored for 12 months under natural environmental conditions (mean temperature $25^{\circ} \mathrm{C}$ ), under refrigeration $(4$ ${ }^{\circ} \mathrm{C}$ ), or in a freezer $\left(-20^{\circ} \mathrm{C}\right)$. We determined their water and oil contents, acidity and peroxide levels, refractive indices, and their fatty acid profiles. The original water content of the seeds was $4.9 \%$, becoming reduced by half during storage. Oil represented $53 \%$ of the seed weight, with lauric acid predominating throughout storage. Theseed oil demonstrated high oxidative stability, with low levels of acidity and peroxide formation, independent of seed origin or storage conditions. The high quality of Attalea vitrivir oil and its stability confirm its potential for agroindustrial use.
\end{abstract}

Keywords: oxidative stability, palm oil, fatty acid profile, oil quality

\section{Introduction}

Vegetable oils are widely used in industry to produce food items, cosmetics, paints and fuels (Ferreira et al., 2012; Siddique et al., 2010). Oleaginous plants are the second most commonly cultivated species in the world (Almeida et al., 2010), with palm trees (Arecaceae) being one of the most economically important groups in tropical regions (Nascimento, 2010). Among the Brazilian oil-producing palms, babaçu (Attalea sp., including the former genera Orbignya, Scheelea, and Maximiliana) is one of the most important natural resources for traditional communities subsistence (Teixeira, 2008; Pintaud, 2008; Lorenzi et al., 2010).

Attalea vitrivir Zona (synonym Orbignya oleifera) occurs in southeastern Brazil (Lorenzi et al., 2010) in areas receiving less rainfall than required by most other species of its group. These palms produce large quantities of fruits from which a starchy flour can be extracted from the mesocarp, the woody endocarp is used for making charcoal, and the oil extracted from the seeds (Lorenzi et al., 2010; Albieiro et al., 2007) can be used for manufacturing foodstuffs, cosmetics, and lubricants (González-Pérez et al., 2012). Because of its wide distribution in Brazil, rusticity, and wide variety of traditional uses, the babaçu palm has been considered for incorporation into programs of biofuel production (EMBRAPA, 1984; Trzeciak et al., 2008; MME, 2014; Pinto et al., 2005). Little is known, however, about the quality of its oil, especially its stability under storage.

Raw material storage is often problematic in agroindustrial production chains. Monitoring the physical and chemical properties of oils is essential to determining adequate conditions for seed storage to minimize deterioration as well as broaden use alternatives (Almeida et al., 2010; Azevedo et al., 2003; Davide et al., 2003). Inadequate storage is associated with autocatalytic and enzymatic hydrolysis of the oil, as well as the 
proliferation of lipolytic microorganisms that facilitate triglyceride hydrolysis (Sambanthamurthi et al., 2000; Piña-Rodriguez \& Jesus, 1992). In spite of the huge potential for the commercial use of natural products from Brazil, there is a notable lack of information available concerning the storage of seeds of native species. Studies focusing on seed storage have largely concentrated on cultivated grains (Orozco-Segovia et al., 2003), and interest has been shown for investigating palm seeds (Carvalho et al., 2015; Neves et al., 2013).

As such, the present study quantified and characterized the oil derived from A. vitrivir seeds and evaluated the influence of storage time and storage conditions on seeds from different regions in terms of oil yields and quality.

\section{Material and Methods}

\subsection{Origin of the Plant Material}

A. vitrivir seeds were harvested from natural populations occurring in the River Pandeiros Environmental Protection Area (APA-Pandeiros), in northern Minas Gerais State, Brazil $\left(15^{\circ} 26^{\prime} 10^{\prime \prime} \mathrm{S} \times 44^{\circ} 40^{\prime} 44^{\prime \prime} \mathrm{W}\right)$. The APA-Pandeiros is located in a transition zone between the Caatinga and Cerrado biomes. The predominant vegetation formations there are Cerrado sensu stricto, gallery forests, and seasonally deciduous forests (Silva et al., 2009). The regional climate is semiarid, with well-defined wet and dry seasons. The mean annual temperature varies between 21 and $24{ }^{\circ} \mathrm{C}$, and the mean annual rainfall varies between 900 and $1200 \mathrm{~mm}$, with rainfall concentrated between November and January (INM, 2012).

Palm seeds were harvested from three areas (A, B and C): Area A showed denser formations of babaçu palms close to the Pandeiros River; Area B was intermediate, with a denser vegetation cover but also with open areas used for pasture and small-scale agro-extractivism; Area $\mathrm{C}$ was composed of open pasture with wide spacing between the trees and shrubs, with a predominance of herbaceous plants. Mature fruits (brown fruits that separate easily from the bunches) were collected directly from five palm trees in each area. The seeds were extracted manually from the harvested fruits using a hatchet.

\subsection{Seed Storage Times and Conditions}

The seeds were stored in polyethylene sacks under room temperature conditions in the laboratory (mean temperature $\left.25^{\circ} \mathrm{C}\right)$, or under refrigeration $\left(4^{\circ} \mathrm{C}\right)$, or in a freezer $\left(-20^{\circ} \mathrm{C}\right)$. Oil analyses and evaluations were performed before initiating storage (zero time) and after three, six, nine, and twelve months.

\subsection{Water Contents}

Seed water contents were determined by the difference between their fresh and dry masses; drying was accomplished in a forced air oven at $105^{\circ} \mathrm{C}$ (MAPA, 2009).

\subsection{Oil Extraction}

To evaluate the physical and chemical properties, the oil was cold extracted by crushing and pressing them using a table-mounted vice. The crude oil was centrifuged for $15 \mathrm{~min}$. at 3500 RPM to remove impurities and then stored in a freezer until analyzed.

\subsection{Oil Contents}

Only fresh non-stored seeds (zero time) and seeds stored for 12 months were used to compare oil contents before and after storage. The oil contents of the seeds were determined through solvent extraction using a Goldfish-type apparatus (Detmann et al., 2012).

\subsection{Determination of Acidic and Peroxide Levels, and the Refractive Index of the Oil}

Analyses were performed on the oil extracted from seeds before storage and after storage for three, six, nine, and twelve months under room temperature, refrigeration, and freezer conditions. The acidic and peroxide levels and refractive indices were determined following the methodologies of the AOCS (1990).

\subsection{Fatty Acid Profiles}

Analyses were performed on babaçu oil extracted from seeds that had not been stored, and from seeds stored for periods of six and twelve months under room temperature, refrigeration, and freezer conditions.

Approximately $12 \mathrm{mg}$ of babaçu oil was dissolved in $100 \mu \mathrm{L}$ of a $95 \%$ ethanol $/ 5 \%$ potassium hydroxide ( 1 mol $\mathrm{L}^{-1}$ ) solution, in a $2 \mathrm{~mL}$ cryogenic tube. After agitation in a vortex mixer for $10 \mathrm{~s}$, the oil was hydrolyzed in a domestic microwave oven (Panasonic Piccolo) for $5 \mathrm{~min}$ at $80 \mathrm{~W}$. After cooling, $400 \mu \mathrm{L}$ of $20 \%$ hydrochloric acid, $\sim 20 \mathrm{mg}$ of $\mathrm{NaCl}$, and $600 \mu \mathrm{L}$ of ethyl acetate were added. After agitation in the vortex mixer for $10 \mathrm{~s}$ and being left to stand for $5 \mathrm{~min}$, a $300 \mu \mathrm{L}$ aliquot was removed from the organic layer, transferred to a 
micro-centrifuge tube, and dried by evaporation-yielding the free fatty acids (adapted from Christie1998). Gas chromatographic analyses were performed as follows: the free fatty acids were methylated using $100 \mu \mathrm{L}$ $\mathrm{BF}_{3} /$ methanol (14\%) by heating for 10 minutes in a water bath at $60{ }^{\circ} \mathrm{C}$, diluted with $900 \mu \mathrm{L}$ of methanol, and subsequently analyzed in a HP7820A Gas Chromatograph (Agilent) equipped with a flame ionization detector. We used a HP-INNOWAX (Agilent) $15 \mathrm{~m} \times 0.25 \mathrm{~mm} \times 0.25 \mu \mathrm{m}$ column with a $70{ }^{\circ} \mathrm{C}, 0 \mathrm{~min} ; 10^{\circ} \mathrm{C} \mathrm{min}^{-1}$ to $240{ }^{\circ} \mathrm{C}$ temperature gradient; injector $(1 / 50$ split $)$ at $250{ }^{\circ} \mathrm{C}$ with the detector at $260{ }^{\circ} \mathrm{C}$. Hydrogen was used as the carrier gas $\left(3 \mathrm{~mL} \mathrm{~min}^{-1}\right)$ and the injection volume was $1 \mu \mathrm{L}$. The identifications of the chromatograph peaks were made by comparisons with FAME C14-C22 methylated fatty acid standards (Supelco cat $\mathrm{n}^{\circ}$ 18917).

\subsection{Experimental Design and Statistical Analyses}

The evaluations of seed water contents, the acidic and peroxide levels of the oil and its refraction index were performed using a random factorial scheme of 3 (seed origin) $\times 3$ (storage conditions) $\times 5$ (time periods), with three repetitions for each treatment. To evaluate the oil content, only the zero and 12 month time periods were used; to evaluate the fatty acid profiles, the zero, six, and 12 month time periods were considered. The data were submitted to analyses of variance, and the means compared using the Tukey test at a $5 \%$ level of probability.

\section{Results}

\subsection{Water Content}

There were no significant differences at time zero between the water contents of the seeds harvested in the three different areas (mean $4.9 \% ; \mathrm{P}=0.1858$ ). During storage, the seed water content decreased to $2.67 \%$, independent of the storage conditions. Maintaining seeds under refrigeration $(\mathrm{M}=3.08 \%)$ resulted in a greater reduction in water content than maintaining them in a freezer $(\mathrm{M}=3.61 \%)$. Storage at room temperature resulted in an intermediate, but not statistically significant, loss of water content $(\mathrm{M}=3.20 \%)$.

\subsection{Oil Content}

No statistically significant differences were observed between the oil contents of seeds harvested from the three different areas at time zero, with a mean of $53.24 \%$ by weight $(\mathrm{P}=0.5061)$. There were slight decreases in lipid contents of these seeds when analyzed after 12 months under all storage conditions, with lesser oil losses from area $\mathrm{C}$ and greater losses from area $\mathrm{A}$; area $\mathrm{B}$ demonstrated intermediate oil content values. Nonetheless, storage conditions did not influence seed oil contents (mean 53.31\%; $\mathrm{P}=0.991$ ).

\subsection{Acidity Levels}

The babaçu seed oil had a mean acidic index of $0.20 \%$ at time zero (Figure 1). Seed storage under freezer and refrigeration conditions maintained the initial acidic level, although a very discreet increase in acidity after nine months of storage under refrigeration conditions was noted. Seeds maintained under room temperature conditions demonstrated greater oil acidity than the other storage methods at all times, with greater acidity values than seen at time zero after nine months of storage; the final acidity level was very slight, however $(M=0.40 \%)$.

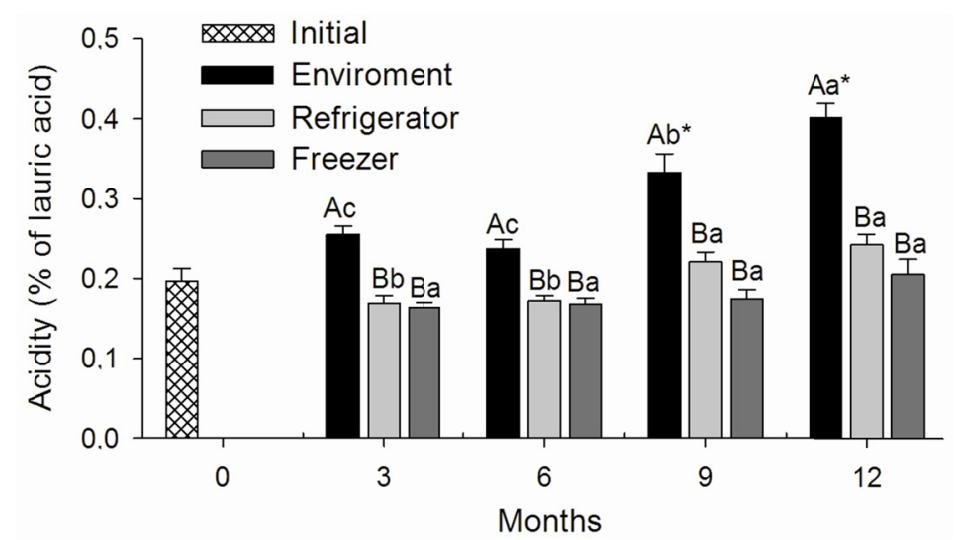

Figure 1. Acidity indices of the oil extracted from Attalea vitrivir seeds stored under different conditions for 12 months. Different letters indicate significant differences by the Tukey test at a 5\% level of probability. Uppercase letters compare storage methods at different times, while lowercase letters compare times within each storage technique. Asterisks indicate significant differences between the treatments and the initial condition. 


\subsection{Peroxide Levels}

Peroxide levels showed interactions between the factors: seed origin $\mathrm{x}$ time of storage, and storage method $\times$ time (Figure 2). At time zero, the peroxide index of the oil did not differ between seeds harvested in areas B and $\mathrm{C}$, with means of 6.94 and $5.17 \mathrm{meq} 1000 \mathrm{~g}^{-1}$, respectively; these means were significantly higher, however, than those observed in area $\mathrm{A}\left(\mathrm{M}=1.35 \mathrm{meq} 1000 \mathrm{~g}^{-1}\right)$ (Figure 2A). No effect of seed origin on the peroxide index during storage was observed, however, and the low peroxide indices observed in all samples after nine and 12 months of storage were not significantly different.

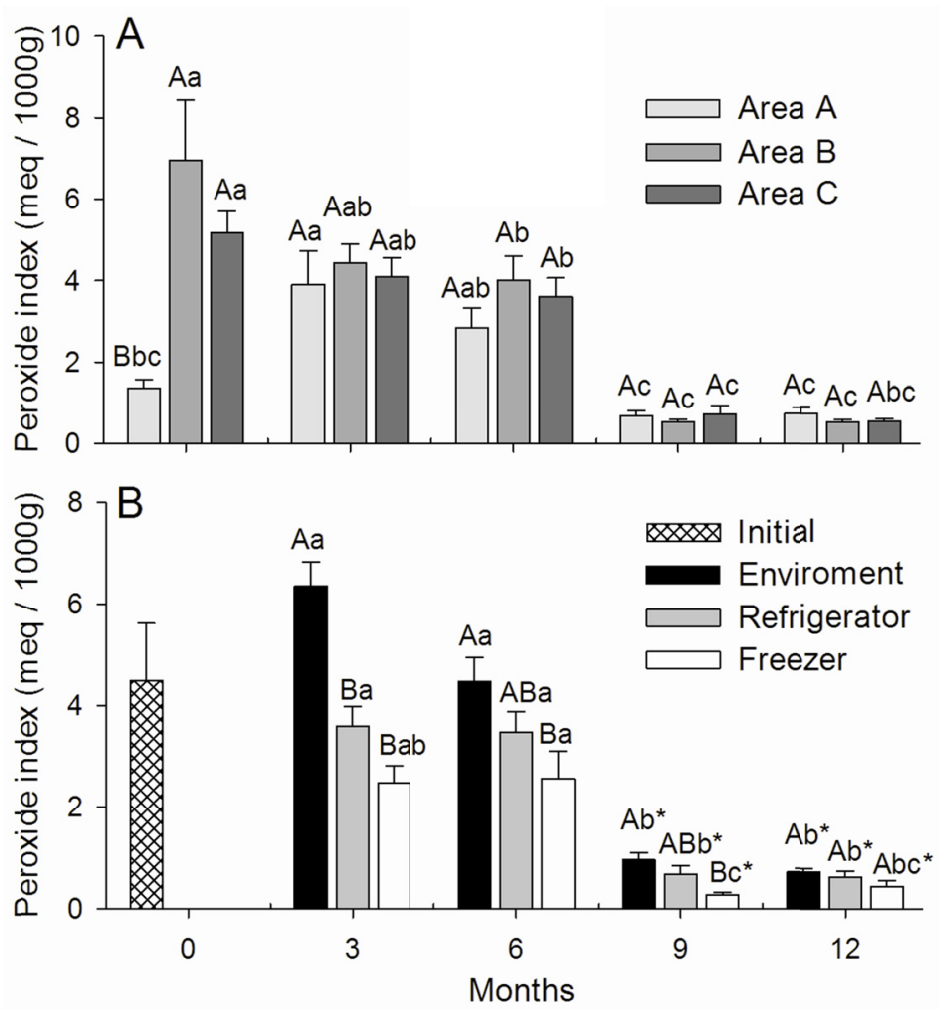

Figure 2. Peroxide indices of the oil extracted from Attalea vitrivir seeds stored for 12 months, as a function of the harvesting site (A) and the storage technique (B). Different letters indicate significant differences by the Tukey test at a 5\% level of significance. Uppercase letters compare harvesting sites (A) or storage techniques (B) within each time frame, while lowercase letters compare the times within each harvesting site or storage technique. The asterisks (B) indicate significant differences between the treatments and the original condition. Vertical bars indicate the mean standard errors

In relation to seed storage conditions, the highest peroxide indices were observed in the oil of seeds stored at room temperature after three months; peroxide levels remained higher in seeds stored at room temperature than in those stored in a freezer after six and nine months (Figure 2B). The peroxide index was consistently lower at time zero than after nine months under all storage conditions; at 12 months there were no statistically significant differences between the three storage methods.

\subsection{Refractive Index}

The refractive indices of the seed oils derived from the three different areas did not differ among themselves at time zero (mean 1.4506; $\mathrm{P}=0.1319)$. Their refractive indices likewise were not affected by storage conditions $(\mathrm{P}$ $=0.5842$ ).

\subsection{Fatty Acid Profiles}

A. vitrivir oil demonstrated a predominance of lauric acid, with the presence of other saturated fatty acids such as myristic (C14:0), palmitic (C16:0), capric (C10:0), caprylic (C8:0), and stearic (C18:0) (Table 1). Unsaturated fatty acids were also identified, including oleic (C18:1) and linoleic (C18:2). There were no significant differences in the proportions of the predominant fatty acids in the seed oils derived from the three different 
areas at time zero: lauric acid $(\mathrm{M}=45.38 \% ; \mathrm{P}=0.1847)$, oleic acid $(\mathrm{M}=15.90 \% ; \mathrm{P}=0.0595)$, and myristic acid $(\mathrm{M}=12.12 \% ; \mathrm{P}=0.1643)$

Table 1. Fatty acid compositions of Attalea vitrivir oils obtained from seeds before and after 6 and 12 months of storage at room temperature $\left(25^{\circ} \mathrm{C}\right)$

\begin{tabular}{|c|c|c|c|c|c|c|c|c|c|c|}
\hline \multirow{3}{*}{ Name } & \multirow{3}{*}{$\mathrm{RT}^{*}(\min )$} & \multicolumn{3}{|c|}{ Before storage } & \multicolumn{3}{|c|}{6 months-room temperature } & \multicolumn{3}{|c|}{12 months-room temperature } \\
\hline & & \multicolumn{3}{|c|}{ Area } & \multicolumn{3}{|c|}{ Area } & \multicolumn{3}{|c|}{ Area } \\
\hline & & $\mathrm{A}$ & $\mathrm{B}$ & $\mathrm{C}$ & $\mathrm{A}$ & B & $\mathrm{C}$ & $\bar{A}$ & $\mathrm{~B}$ & $\mathrm{C}$ \\
\hline C8:0 & 1.58 & 7.03 & 6.47 & 5.77 & 6.83 & 6.91 & 6.06 & 7.24 & 6.83 & 5.85 \\
\hline $\mathrm{C} 10: 0$ & 3.14 & 7.94 & 7.36 & 6.64 & 7.85 & 7.64 & 6.99 & 8.22 & 7.55 & 6.80 \\
\hline $\mathrm{C} 12: 0$ & 5.10 & 46.57 & 45.24 & 44.32 & 46.73 & 45.85 & 45.84 & 47.26 & 45.69 & 45.41 \\
\hline C14:0 & 7.00 & 11.65 & 12.34 & 12.38 & 11.63 & 12.20 & 12.26 & 11.55 & 12.35 & 12.49 \\
\hline C16:0 & 8.83 & 7.23 & 8.01 & 8.16 & 7.17 & 7.72 & 7.65 & 7.01 & 7.82 & 7.99 \\
\hline C18:0 & 10.54 & 2.92 & 3.04 & 3.08 & 2.90 & 2.99 & 3.05 & 3.14 & 3.09 & 3.36 \\
\hline C18:1 & 10.69 & 14.80 & 15.50 & 17.41 & 14.65 & 14.76 & 16.06 & 13.93 & 14.82 & 16.10 \\
\hline C18:2 & 11.05 & 1.87 & 2.03 & 2.24 & 2.24 & 1.93 & 2.09 & 1.66 & 1.86 & 1.99 \\
\hline
\end{tabular}

Note. ${ }^{*}$ Retention Time.

The storage conditions and times of storage did not significantly affect the proportions of fatty acids, with significant differences between the oils of seeds derived from the three different areas being noted only for $\mathrm{C} 18: 1(\mathrm{P}=0.470)$. In this case, area $\mathrm{C}$ demonstrated the greatest proportion of that fatty acid $(\mathrm{M}=16.4 \%)$ in comparisons to areas $\mathrm{B}(\mathrm{M}=14.8 \%)$ and $\mathrm{A}(\mathrm{M}=15.0 \%)$. The oil from seeds harvested in area A showed a higher percentage of saturated fatty acids $(\mathrm{M}=83.3 \%)$ at time zero than the oil from area $\mathrm{C}(\mathrm{M}=80.4 \%)$; the oil from area $\mathrm{B}(\mathrm{M}=82.5 \%)$ did not differ significantly from the others in that respect. The storage periods did not significantly alter the percentages of saturated oils from any of the three areas $(\mathrm{P}=0.1691)$, with only a slightly lower value in area $C(M=81.5)$ than observed in areas $A(M=83.0 \%)$ or $B(M=83.2)$.

\section{Discussion}

The oil yields from the seeds analyzed in the present work (mean 53.24\%) were lower than the means reported in most studies of babaçu species (Attalea sp.), with lipidic contents generally above 60\% (Machado et al., 2006; Soler et al., 2007; Gioielli, 1996; Cadernos NAE, 2005). The value found here was, however, greater than that reported by Guedes et al. (2015), who encountered a mean oil content of 45.7\% in Attalea vitrivir seeds from the same general region as the present work, although they used a different extraction technique. Lipidic values near those reported here were encountered in macaúba palm (Acrocomia aculeata) seeds (54\%) (Hiane et al., 2005), and higher than the values found for three populations of Acrocomia emensis, with a mean of $13.45 \%$ (Neiva et al., 2018). The value found here was also higher than the found in Bacaba, Buriti, Inajá, Pupunha and Tucumã, $22.1 \%, 10.6 \%, 14.6 \%, 5.9 \%, 11.8 \%$, respectively (Santos et al., 2013a); in Inajá with 35.5\% (Rodrigues et al., 2010).

The water contents of the seeds analyzed in the present study were very close to those previously reported for the same species that disperse seeds with low humidity levels and demonstrate orthodox behavior under storage (Silva et al., 2009). Oleaginous seeds should always be stored with low humidity levels that favor lipid conservation, as alterations of their oils are principally due to hydrolysis, whether enzymatic or autocatalytic (Peske et al., 2012; McDonald, 1999). The low initial humidity levels of freshly harvested seeds of $A$. vitrivir, and their tendency to dehydrate during storage, contribute to the maintenance of oil quality and will facilitate their management for agroindustrial purposes.

The low acidity of the oil in recently-harvested seeds and the absence of any discernible effects due to their geographic origins have been reported for other palms of the genus Attalea (Ferreira et al., 2012; Lima et al., 2007). The maximum acidic values reported here, even under conditions of room temperature storage, are still below the recommended limits for human consumption of unrefined oils, and even below that expected for refined oils (ANVISA, 2005). These acidic values are considered adequate for the oil to be used for biodiesel production, as the transesterification reactions that use hydroxides as catalyzing agents are sensitive to excessive free fatty acids (which favor saponification reactions and compete with transesterification) (Lima et al., 2007).

Oxidation is also an important cause of lipid deterioration through the formation of free radicals that subsequently form peroxides and hydroperoxides. The occurrence of oxidation can therefore be estimated by 
determining the peroxide index (Silva et al., 1999; Madhavi et al., 1996; Farmer et al., 1942; Toledo et al., 1985). The significant differences observed between the peroxide values in the three different harvesting areas may be related to genetic or environmental factors - although these differences were later neutralized by the dynamics of chemical reactions associated with storage. Nascimento et al. (2009) reported the peroxide concentration in babaçu oil to be $1.136 \mathrm{meq} 1000 \mathrm{~g}^{-1}$, a value very similar to that observed in area $\mathrm{A}$ in the present work. Variations in peroxide indices are quite common among oleaginous seeds(Ferreira et al., 2012; Hiane et al., 2005), although the A. vitrivir oil analyzed here demonstrated peroxide values significantly lower than commonly encountered in unprocessed oils (15 meq $1000 \mathrm{~g}^{-1}$ ) (ANVISA, 2005), indicating a low level of oxidative degradation (Malacrida \& Jorge, 2003).

It is interesting to note that there were actually reductions in peroxide levels after nine months of storage related to the dynamics of oil degradation - as the free radicals initially formed will normally be converted into other radicals, forming peroxides and hydroperoxides that combine and give rise to stable products such as aldehydes, alcohols, and hydrocarbons (Silva et al., 1999; Madhavi et al., 1996; Farmer et al., 1942; Toledo et al., 1985). The peroxide index therefore represents the difference between the formation and decomposition of reactive species. It is important to note, however, that the maximum values reported here for $A$. vitrivir were still very much below the levels considered indicators of significant oil degradation (ANVISA, 2005; Malacrida \& Jorge, 2003).

Hydrolysis and oxidation are the principal mechanisms of fat and oil rancidification, and they are associated with reactions of water or atmospheric oxygen with fatty acids, principally unsaturated fatty acids (P. A. Bobbio \& F. O. Bobbio, 1992). The absence of double bonds in the carbon backbones of saturated fatty acids makes them more stable and more resistant to degradation processes (Luz et al., 2011). The refractive indices of fatty acids are a reflection of their degrees of saturation, and the values encountered in the present study are similar to those reported in the literature (Machado et al., 2006; Codex, 2001). A. vitrivir oil was found to be rich in saturated fatty acids, especially lauric acid-a result expected according to previous descriptions of babaçu oil in the literature (Ferreira et al., 2012; Lima et al., 2007; Santos et al., 2013b; Gonzalez et al., 2008). Similar results have also been reported for oils extracted from the seeds of other palm trees, such as Astrocaryum aculeatum G. Mey (Barbosa et al., 2009) and Cocos nucifera L., among others (Bereau et al., 2003). Storage time was not found to have a significant influence on the quantity or the composition of the oil extracted from A. vitrivir seeds, with its low acidity and peroxide levels even after storage for one year at room temperature. It is probable that the chemical stability of the oil is largely due to its high concentrations of saturated fatty acids. However, Queiroga et al. (2015) in their studies with Orbignya sp. report that the storage time can influence from the physical-chemical characteristics to the oil content.

The maintenance of A. vitrivir oil in intact seeds contributes to its conservation during storage, as only small changes were observed in its physical and chemical properties even after storage for one full year at room temperature. Another advantage of this situation resides in the ease of storage and transport of the seeds, as they will not require complex or costly storage conditions as compared to extracted oil. The storage of $A$. vitrivir seeds for agroindustrial uses requires only the simplest conditions and will thus complement the exceptional agricultural/commercial potential of the species (Silva et al., 2009; Guedes et al., 2015). In situations where more sophisticated applications of the oil might demand greater levels of conservation, refrigeration will provide numerous benefits, as is usual in seed storage (Delouche, 1968; Ordóñez, 2005).

\section{Conclusions}

Attalea vitrivir seeds contain high oil concentrations, equivalent to more than half of their total mass. The oil is largely composed of saturated fatty acids, such as lauric acid. The composition of the oil lends it a considerable level of oxidative stability, which is confirmed by its low observed acidic and peroxide indices. Simple storage conditions will guarantee the maintenance of seed oil quality, with low temperatures promoting even more efficient conservation of its characteristics. No significant differences in oil quality were observed between the harvesting sites, or between freshly harvested seeds and those stored for up to a year. The characteristics of the oil and its resistance to chemical alterations during storage indicate this species' exceptional potential for agroindustrial use.

\section{Acknowledgements}

We thank the Fundação de Amparo à Pesquisa do Estado de Minas Gerais (FAPEMIG) for the financial support given to Marcio Antonio Silva Pimenta (Process CBB-APQ-01552-08), for the BIPDT grants awarded to M.A.S. Pimenta and H.M. Valério, and for the PCRH (Programa de Capacitação de Recursos Humanos) grant awarded to Sônia Ribeiro Arrudas; the Conselho Nacional de Desenvolvimento Científico e Tecnológico (CNPq) for the 
financial support given to Marcio Antonio Silva Pimenta (Process 477480/2011-0); the Programa de Formação de Recursos Humanos da Petrobras (PFRH-PB 225); the Coordenação de Aperfeiçoamento de Pessoal de Nível Superior (CAPES) for the Masters' grant awarded to H.F. Salvador; and Unimontes for logistic support.

\section{References}

Albieiro, D., Maciel, A. J. S., Lopes, A. C., Mello, C. A., \& Gamero, C. A. (2007). Proposta de uma máquina para colheita mecanizada de babaçu (Orbignya phalerata Mart.) para a agricultura familiar. Acta Amazônica, 37, 337-346. https://doi.org/10.1590/S0044-59672007000300004

Almeida, F. A. C., Jerônimo, E. S., Alves, N. M. C., Gomes, J. P., \& Silva, A. S. (2010). Estudo de técnicas para o armazenamento de cinco oleaginosas em condições ambientais e criogênicas. Revista Brasileira de Produtos Agroindustriais, 12(2), 189-202. https://doi.org/10.15871/1517-8595/rbpa.v12n2p189-202

ANVISA (Agência Nacional de Vigilância Sanitária). (2005). Resolução $R D C n^{\circ} 270$, de 22 de setembro de 2005.

AOCS (American Oil Chemistis' Society). (1990). Official methods and recommended practices of the American Oil Chemists' Society. A.O.C.S., Champaign.

Azevedo, M. R. Q. A., Gouveia, J. P. G., Trovão, D. M. M., \& Queiroga, V. P. (2003). Influência das embalagens e condições de armazenamento no vigor de sementes de gergelim. Revista Brasileira de Engenharia Agricola e Ambiental, 7(3), 519-524. https://doi.org/10.1590/S1415-43662003000300019

Barbosa, B. S., Koolen, H. H. F., Barreto, A. C., Silva, J. D., Figliuolo, R., \& Nunomura, S. M. (2009). Aproveitamento do óleo das amêndoas de Tucumã do Amazonas na produção de Biodiesel. Acta Amazônica, 39, 371-376. https://doi.org/10.1590/S0044-59672009000200015

Bereau, D., Benjelloun-Mlayah, B., Banoub, J., \& Bravo, R. (2003). FA and unsaponifiable composition of five Amazonian palm kernel oils. Journal of the American Oil Chemists' Society, 80(1), 49-53. https://doi.org/ $10.1007 / \mathrm{s} 11746-003-0649-5$

MME (Ministério de Minas e Energia). (2014). Biodiesel: Programa Nacional de Produção e Uso de Biodiesel. Retrieved from http://www.mme.gov.br/programas/biodiesel

Bobbio, P. A., \& Bobbio, F. O. (1992). Química do processamento de alimentos (p. 71). Livraria Varela Ltda, São Paulo.

Cadernos NAE (Núcleo de Assuntos Estratégicos da Presidência da República). (2005). Biocombustíveis. Núcleo de Assuntos Estratégicos da Presidência da República, Secretaria de Comunicação de Governo e Gestão Estratégica, Brasília, Brazil.

Carvalho, V. S., Ribeiro, L. M., Lopes, P. S. N., Agostinho, C. O., Matias, L. J., Mercadante-Simões, M. O., \& Correia, L. N. F. (2015). Dormancy is modulated by seed structures in palms of the cerrado biome. Australian Journal of Botany, 63(5), 444-454. https://doi.org/10.1071/BT14224

Christie, W. W. (1998). Gas chromatography-mass spectrometry methods for structural analysis of fatty acids. Lipids, 33, 343-353. https://doi.org/10.1007/s11745-998-0214-X

Codex Alimentarius. (2001). Codex standard for named vegetable oils. Codex Alimentarius, 8, 11-25.

Davide, A. C., Carvalho, L. R., Carvalho, M. L. M., \&Guimarães, R. M. (2003). Classificação fisiológica de sementes de espécies florestais pertencentes à família Lauraceae quanto à capacidade de armazenamento. Revista Cerne, 9, 29-35.

Delouche, J. C. (1968). Short Course for Seedsmen. State College, Mississippi State University.

Detmann, E., Souza, M. A., Valadares Filho, S. C., Queiroz, A. C., Berchielli, T. T., Saliba, E. O. S., ... Azevedo, J. A. G. (2012). Métodos para Análise de Alimentos-INCT-Ciência Animal. Suprema, Visconde do Rio Branco.

EMBRAPA (Empresa Brasileira de Pesquisa Agropecuária). (1984). Babaçu, Programa Nacional de Pesquisa (p. 89). Embrapa: Brasília, Brazil.

Farmer, E. H., Bloomfield, G. G., Sundaralingam, S., \& Sutton, D. A. (1942). The course and mechanism of autoxidation reactions in olefinic and polyolefinic substances, including rubber. Transactions of the Faraday Society, 38, 348-356. https://doi.org/10.1039/tf9423800348 
Ferreira, B.S., Faza, L. P., \& Hyaric, M. L. (2012). A comparison of the physicochemical properties and fatty acid composition of indaiá (Attalea dubia) and babassu (Orbignya phalerata) oils. The Scientific World Journal, 4. https://doi.org/10.1100/2012/532374

Gioielli, L. A. (1996). Óleos e gorduras vegetais: Composição e tecnologia. Revista Brasileira de Farmacognosia, 5(2), 211-232. https://doi.org/10.1590/S0102-695X1996000200008

Gonzalez, W. A., Machado, C. R., Barreto, E. J. F., Dall'Oglio, E. L., Correia, J. C., Borges, L. E. P., ... Rodrigues, V. (2008). Biodiesel e óleo vegetal in natura: Soluções energéticas para a Amazônia (p. 168). Ministério de Minas e Energia, Brasília, Brazil.

González-Pérez, S. E., Coelho-Ferreira, M., Robert, P., \& Garcés, C. L. L. (2012). Conhecimento e usos do babaçu (Attalea speciosa Mart. E Attalea eichleri (Drude) A. J. Hend.) entre os Mebêngôkre-Kayapó da Terra Indígena Las Casas, estado do Pará, Brasil. Acta Botânica Brasilica, 26, 295-308. https://doi.org/ $10.1590 / \mathrm{S} 0102-33062012000200007$

Guedes, M. L., Ferreira, P. H. G., Santana, K. N. O., Pimenta, M. A. S., \& Ribeiro, L. M. (2015). Fruit morphology and productivity of babassu palms in northern Minas Gerais state, Brazil. Revista Árvore, 39, 883-892. https://doi.org/10.1590/0100-67622015000500011

Hiane, P. A., Filho, M. M. R., Ramos, M. I. L., \& Macedo, M. L. R. (2005). Óleo da polpa e amêndoa de bocaiúva, Acrocomia aculeata (Jacq.) Lodd. Caracterização e composição em ácido graxos. Brazilian Journal of Food Technology, 8(3), 256-259.

INM (Instituto Nacional de Metereologia). (2012). Retrieved from http://www.inmet.gov.br

Lima, J. R. O., Silva, R. B., Silva, C. C. M., Santos, L. S. S., Santos Jr., J. R., Moura, E. M., \& Moura, C. V. R. (2007). Biodiesel de babaçu (Orbignya sp.) obtido por via etanólica. Quimica Nova, 30, 600-603. https://doi.org/10.1590/S0100-40422007000300019

Lorenzi, H., Noblick, L., Kahn, F., \& Ferreira, E. (2010). Flora Brasileira: Arecaceae (Palmeira). Nova Odessa: São Paulo.

Luz, D. A., Machado, K. R. G., Pinheiro, R. S., Maciel, A. P., Souza, A. G., \& Silva, F. C. (2011). Estudos físico-químicos do óleo de babaçu bruto (Orbignya phalerata Mart.) e de um subproduto da etapa de degomagem do processo de refino. Cadernos de Pesquisa, 18(3), 19-22.

Machado, G. C., Chaves, J. B. P., \& Antoniassi, R. (2006). Composição em ácidos graxos e caracterização física e química de óleos hidrogenados de coco babaçu. Revista Ceres, 53, 463-470.

Madhavi, D. L., Deshpande, S. S., \& Salunkhe, D. K. (1996). Food Antioxidants: Technological: Toxicological and Health Perspectives. New York, USA.

Malacrida, C. R., \& Jorge, N. (2003). Alterações do óleo de soja e da mistura azeite de dendê - óleo de soja em frituras descontínuas de batatas chips. Brazilian Journal of Food Technology, 6(2), 245-249.

MAPA (Ministério da Agricultura, Pecuária a Abastecimento). (2009). Regras para análise de sementes. MAPA, Brasília, Brazil.

McDonald, M. B. (1999). Seed deterioration: Physiology, repair and assessment. Seed Science Technology, 27, 177-237.

Nascimento, A. R. T. (2010). Riqueza e etnobotânica de palmeiras no território indígena Krahô, Tocantins, Brasil. Floresta, 40, 209-220. https://doi.org/10.5380/rf.v40i1.17112

Nascimento, U. M., Vasconcelos, A. C. S., \& Azevedo, E. B. (2009). Otimização da produção de biodiesel a partir de óleo de coco babaçu com aquecimento por microondas. Ecletica Química, 34(4), 37-48. https://doi.org/10.1590/S0100-46702009000400004

Neiva, D. S., Rocha, J. A., Melo Junior, A. F., Oliveira, D. A., Brandão, M. M., Ferraz, V. P., Royo, V. A., \& Menezes, E. V. (2018). Physical-Chemical characterization and fatty acid profile of the Acrocomia emensis (Arecaceae) seed oil. Journal of Agricultural Science, 10(1), 264-271. https://doi.org/10.5539/jas.v10 n1p264

Neves, S. C., Ribeiro, L. M., Cunha, I. R. G., Pimenta, M. A. S., Mercadante-Simões, M. O., \& Lopes, P. S. N. (2013). Diaspore structure and germination ecophysiology of the babassu palm (Attalea vitrivir). Flora, 208, 68-78. https://doi.org/10.1016/j.flora.2012.12.007 
Ordóñez, J. A. (2005). Tecnologia de alimentos: Componentes dos alimentos e processos (Vol. 1). Artmed, Porto Alegre.

Orozco-Segovia, A., Batis, A. I., Rojas-Aréchiga, M., \& Mendonza, A. (2003). Seed biology of palms: A review. Palms, 47, 79-94.

Peske, S. T., Villela, F. A., \& Meneghello, G. E. (2012). Sementes: Fundamentos cientificos e tecnológicos. Becker \& Peske Ltda, Pelotas (3rd ed., p. 573). Pelotas: Editora Universitária / UFPel.

Piña-Rodriguez, F. C. M., \& Jesus, R. M. (1992). Comportamento das sementes de cedro-rosa (Cedrela angustifolia S. ET. MOC) durante o armazenamento. Revista Brasileira de Sementes, 14, 31-36. https://doi.org/10.17801/0101-3122/rbs.v14n1p31-36

Pintaud, J. C. (2008). An overview of the taxonomy of Attalea (Arecaceae). Revista Peruana de Biologia, 15(1), 55-63.

Pinto, A. C., Guarieiro, L. L. N., Rezende, M. J. C., Ribeiro, N. M., Torres, E. A., Lopes, W. A., ... Andrade, J. B. (2005). Biodiesel: An overview. Journal of the Brazilian Chemical Society, 16, 1313-1330. https://doi.org/ 10.1590/S0103-50532005000800003

Queiroga, V. P., Girão, E. G., Araújo, I. M. S., Gondim, T. M. S., Freire, R. M. M., \& Veras L. G. C. (2015). Composição centesimal de amêndoas de coco babaçu em quarto tempos de armazenamento. Revista Brasileira de Produtos Agroindustriais, 17(2), 207-213. https://doi.org/10.15871/1517-8595/rbpa.v18n2p 207-225

Rodrigues, A. M. C., Darnet, S., \& Silva, L. H. M., (2010). Fatty acid profiles tocopherol of buriti (Mauritia flexuosa), patawa (Oenocarpus bataua), tucumã (Astrocaryum vulgare) mari (Poraqueiba paraensis) and inajá (Maximiliana maripa) fruits. Journal of Brazilian Chemical Society, 21, 2000-2004. https://doi.org/ 10.1590/S0103-50532010001000028

Sambanthamurthi, R., Sundram, K., \& Tan, Y. (2000). Chemistry and biochemistry of palm oil. Progress in Lipid Research, 39, 507-558. https://doi.org/10.1016/S0163-7827(00)00015-1

Santos, M. F. G., Marmesat, S., Brito, E. S., Alves, R. E., \& Dobarganes, M. C. (2013a). Major components in oils obtained from Amazonian palm fruits. Grasas Y Aceites, 64(3), 328-334. https://doi.org/10.3989/gya. 023513

Santos, D. S., Silva, I. G., Araújo, B. Q., Lopes Jr., C. A., Monção, N. B. N., Citó, A. M. G. L., ... Costa, M. C. P. (2013b). Extraction and evaluation of fatty acid compositon of Orbignya phalerata Martius oils (Arecaceae) from Maranhão State, Brazil. Journal of the Brazilian Chemical Society, 24, 355-362. https://doi.org/10.5935/0103-5053.20130045

Siddique, B. M., Ahmad, A., Ibrahim, M. H., Hena, S., Rafatullah, M., \& Mohd Omar, A. K. (2010). Physico-chemical properties of blends of palm olein with other vegetable oils. Grasas Y Aceites, 61(4), 423-429. https://doi.org/10.3989/gya.010710

Silva, A. M. F., Borges, M. F. M., \& Ferreira, M. A. (1999). Métodos para avaliação do grau de oxidação lipídica e da capacidade antioxidante. Quimica Nova, 22, 94-103. https://doi.org/10.1590/S0100-40421 999000100016

Silva, J. O., Jesus, M. F., Fagundes, M., \& Fernandes, G. W. (2009). Esclerofilia, taninos e insetos herbívoros associados a Copaifera lagsdorffii Desf. (Fabaceae: Caesalpinioideae) em área de transição Cerrado-Caatinga no Brasil. Ecologia Austral, 19, 197-206.

Soler, M. P., Vitali, A. A., \& Muto, E. F. (2007). Tecnologia de quebra do coco babaçu (Orbignya speciosa). Ciência e Tecnologia de Alimentos, 27(4), 717-722. https://doi.org/10.1590/S0101-20612007000400007

Teixeira, M. A. (2008). A new approach for an ancient Brazilian biomass. Biomass Bioenergy, 32, 857-864. https://doi.org/10.1016/j.biombioe.2007.12.016

Toledo, M. C. F., Esteves, W., \& Hartmann, E. M. (1985). Eficiência de antioxidantes em óleo de soja. Ciência e Tecnologia de Alimentos, 5, 1.

Trzeciak, MB, Neves, M. B., Vinholes, O. S., \& Villela, F. A. (2008). Utilização de sementes de espécies oleaginosas para produção de biodiesel. Informativo ABRATES, 18, 30-38. 


\section{Copyrights}

Copyright for this article is retained by the author(s), with first publication rights granted to the journal.

This is an open-access article distributed under the terms and conditions of the Creative Commons Attribution license (http://creativecommons.org/licenses/by/4.0/). 